\title{
Zastosowanie filmów radiochromowych w weryfikacji rozkładów dawek w brachyterapii. Przygotowanie do wprowadzenia algorytmów zaproponowanych przez TG-186 AAPM
}

\section{Use of radiochromic films in verification of dose distributions in brachytherapy. Preparation for the introduction of algorithms proposed by TG-186 AAPM}

\author{
Grzegorz Bielęda ${ }^{1,2}$ \\ ${ }^{1}$ Zakład Fizyki Medycznej, Wielkopolskie Centrum Onkologii w Poznaniu \\ ${ }^{2}$ Katedra i Zakład Elektroradiologii, Wydziat Nauk o Zdrowiu, Uniwersytet Medyczny w Poznaniu
}

\section{Streszczenie}

Weryfikacja rozkładów dawki w brachyterapii stawia przed fizykami medycznymi wiele wyzwań. Ze względu na wysoki gradient dawki pomiary wymagają bardzo dużej higieny pracy oraz wysokiej dokładności. Do tej pory stosowane były algorytmy do obliczenia rozkładów dawek zaimplementowane w systemach planowania leczenia wprowadzone przez TG-43 AAPM (ang. Task Group 43 of American Association of Physicists in Medicine - Grupa Zadaniowa Amerykańskiego Towarzystwa Fizyki Medycznej). Charakteryzują się one przede wszystkim tym, że przyrównują współczynniki osłabienia promieniowania ośrodka, w którym rozchodzi się promieniowanie do współczynnika osłabienia promieniowania wody. Taka sama procedura jest zastosowana dla ośrodka, w którym obliczana jest dawka pochłonięta. Wprowadzenie przez grupę TG-186 AAPM nowych algorytmów obliczających rozkłady dawek, uwzględniających rzeczywiste współczynniki osłabienia i pochłaniania promieniowania wymagają bardziej szczegółowych i dokładnych procedur kontroli jakości przygotowanych planów leczenia $\mathrm{w}$ brachyterapii. W niniejszej pracy omówiono najnowsze doniesienia dotyczące weryfikacji rozkładów dawek w brachyterapii z uwzględnieniem doniesień przedstawionych w trakcie konferencji naukowej 3rd ESTRO Forum, która odbyła się w 2015 roku w Barcelonie.

\footnotetext{
Abstract

Adres do korespondencji

mgr Grzegorz Bielęda

Starszy Asystent

Wielkopolskie Centrum Onkologii,ul. Garbary 15, 61-866 Poznań, Polska

Telefon: +48618850819

e-mail: grzegorz.bieleda@wco.pl
}

Verification of brachytherapy dose distributions is a challenging task for medical physicists. Due to a very steep dose gradient, measurements require a very high hygiene and accuracy. Until now, the algorithms introduced by the task group TG-43 of AAPM (American Association of Physicists in Medicine have been used to calculate the dose distributions implemented in the treatment planning systems). These algorithm 
main characteristic is that the radiation attenuation coefficient in the entire calculated volume is equated to radiation attenuation coefficient of water. Introduction by the AAPM TG-186 of new algorithms for calculating dose distributions, taking into account the actual coefficients of attenuation and absorption of radiation require a more detailed and accurate quality control procedures for prepared treatment plans in brachytherapy. This paper discusses the latest reports on verification of dose distributions presented at the 3rd ESTRO Forum held in 2015 in Barcelona.

Stowa kluczowe: brachyterapia; pomiar dawki; filmy radiochromowe

Key words: brachytherapy; dose measurement; radiochromic films

\section{Nowe algorytmy do obliczania rozkładów dawek w brachyterapii}

Zaprojektowanie i wprowadzenie skutecznych metod weryfikacji systemów planowania leczenia (ang. Treatment Planning System, TPS) stosowanych w brachyterapii jest w większości przypadków przedsięwzięciem bardzo złożonym [1, 2]. TPS stosowany w większości przypadków nadal opiera się na zaleceniach TG-43 AAPM (ang. Task Group 43 of American Association of Physicists in Medicine - Grupa Zadaniowa Amerykańskiego Towarzystwa Fizyki Medycznej), które zostały sprawdzone przez wielu autorów w jednorodnych warunkach [3]. Jednak jedną z dobrze znanych wad algorytmów obliczeniowych jest to, że takie obliczenia dawki opierają się na jednej pozycji źródłowej w jednorodnym środowisku wodnym $[4,5]$. Całkowity rozkład dawki w ośrodku jest produktem sumy rozkładu dawki pochodzącej od każdej pozycji źródła, które są obliczane przez algorytm optymalizacyjny [6, 7].

Trójwymiarowa rekonstrukcja geometrii jest powszechną techniką [8, 9], ale korzyści ze stosowania tych metod obrazowania nie zostały w pełni zrealizowane z powodu braku użytecznej informacji o budowie materii, która zależy nie tylko od gęstości elektronowej, ale również od liczby atomowej (Z) samego aplikatora i otaczających tkanek [10]. W rezultacie względnie niskie energie stosowane w brachyterapii uniemożliwiają określenie wpływu niejednorodności w obliczeniach dawki. Zalecenia grupy zadaniowej TG-186 AAPM zapewniają większą dokładność w dozymetrii brachyterapii. Grupa ta zaleca użycie algorytmów opartych na budowie materii ( ang. Model Based Dose Calculation Algorithms, MBDCA) i podkreśla potrzebę dokładnej segmentacji tkanki identyfikując rodzaj tkanki pod względem gęstości i składu pierwiastkowego $[11,12]$. Jednakże w odniesieniu do klinicznego stosowania tych nowych metod obliczeniowych, potrzebne są wiarygodne i powtarzalne metody weryfikacji TPS.

\section{Weryfikacja rozkładów dawek}

Porównania rozkładów dawek dokonać można stosując dwuwymiarową analizę współczynnika gamma. Analiza współczynnika gamma stosowana jest od lat dla planów IMRT (ang. Intensity-modulated Radiatiotherapy, radioterapia $\mathrm{z}$ modulowaniem intensywności wiązki), ponieważ jest to standardowy proces weryfikacji dozymetrycznej zaplanowanych planów leczenia przed ich akceptacją. Autorzy raportu TG-119 AAPM zalecają, właśnie dla IMRT, zastosowanie akceptowalności na poziomie 90\% współczynnika o wartości mniejszej lub równej 1, przy kryteriach analizy 3\%/3 mm. Są jednak ośrodki, w których kryterium to jest bardziej surowe i plany akceptowane są dopiero na poziomie 95\%. Nie ma natomiast jednogłośnej opinii w sprawie kryteriów na potrzeby brachyterapii. We wielu pracach zamieszczano własne propozycje wartości kryteriów i poziomu akceptacji planów (np. 10\%/2 mm [13], 5\%/2 mm [14]), jednak i tak najczęściej stosowanym kryterium, zarówno w teleradioterapii, jak i brachyterapii pozostały 3\% różnica w dawce lokalnej dla danego punktu znajdującego się w odległości do 3mm [15]. Rycina 1 przedstawia przykładowy wynik weryfikacji zrealizowanego rozkładu dawki.

Raport przygotowany przez 186 grupę zadaniową AAPM zakłada weryfikację algorytmów optymalizacyjnych opartych na budowie materii na dwóch poziomach:

- Obliczenia rozkładów dawek w warunkach oddających założenia raportu TG-43.

- Obliczenia rozkładów dawek w warunkach klinicznych i porównanie ich z symulacjami Monte Carlo. 
W czasie konferencji 3rd ESTRO Forum temat weryfikacji zaawansowanych algorytmów optymalizacyjnych w planowaniu brachyterapii został poruszony w sesji ustnej, jak i plakatowej [16, 17]. Zastosowanie algorytmów MDCA wymaga jednak na początku określenia zgodności obliczonych rozkładów dawek w takich samych warunkach, w jakich są obliczane w oparciu o zalecenia TG-43. W tym celu należy przygotować plan leczenia dla pojedynczego punktu postoju źródła w fantomie wodnym o wymiarach co najmniej $40 \times 40 \times 40 \mathrm{~cm}^{3}$. Sugerowane jest porównanie rozkładów dawek w całej objętości. Dodatkowo autorzy raportu sugerują „ręczne” obliczenia dawek w kilku punktach w oparciu o dostępne tabele opisujące osłabienie promieniowania dookoła źródła promieniotwórczego. Jeśli rozkłady dawki będą zgodne na założonym poziomie dokładności, można przejść do kolejnego etapu weryfikacji. Dla zminimalizowania niepewności pomiarowych należy sprawdzać najprostsze do zrealizowania układy, które mają zastosowanie kliniczne w ośrodku przeprowadzającym weryfikację. Badacze powinni weryfikować jedynie układy, które realizują rutynowo w swojej praktyce, aby zminimalizować prawdopodobieństwo wystąpienia potencjalnych błędów przy budowie układu pomiarowego oraz przy realizacji zaplanowanych badań.

Ze względu na bardzo duży gradient dawki wykonanie rzetelnych pomiarów rozkładów dawek w brachyterapii jest zadaniem niełatwym, a kluczowym dla uzyskania wiarygodnych wyników. Minimalne przesunięcie filmu dozymetrycznego lub aplikatora w układzie pomiarowym powoduje wystąpienie bardzo dużych błędów pomiarowych. Zaprojektowanie układu pomiarowego zapewniającego jak największą precyzję i powtarzalność uzyskiwanych wyników powinno być zasadniczym zadaniem fizyków medycznych przygotowujących się do wprowadzenia algorytmów MBDCA. Weryfikacja poprawności realizacji planów leczenia przygotowanych przy użyciu coraz bardziej zaawansowanych algorytmów optymalizacyjnych jest niezbędne dla utrzymania wysokiej jakości leczenia i bezpieczeństwa pacjentów [18].
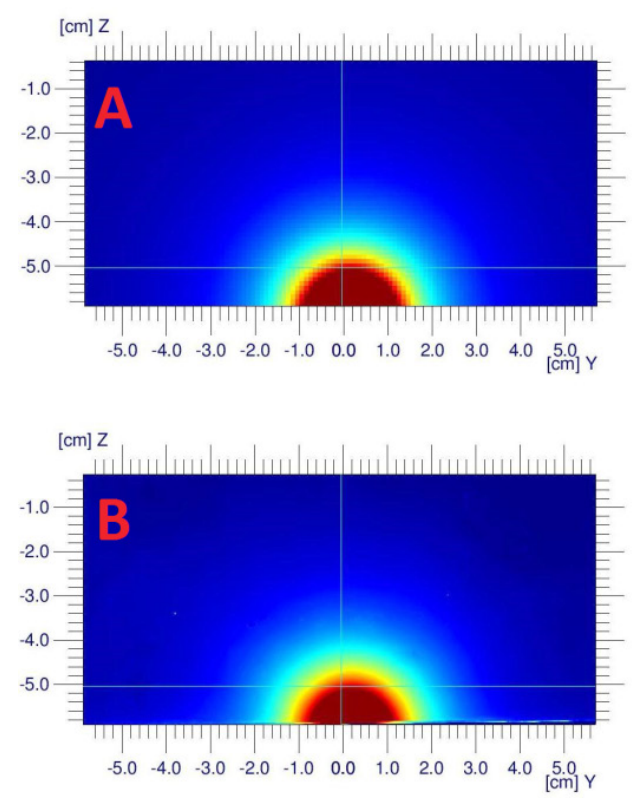
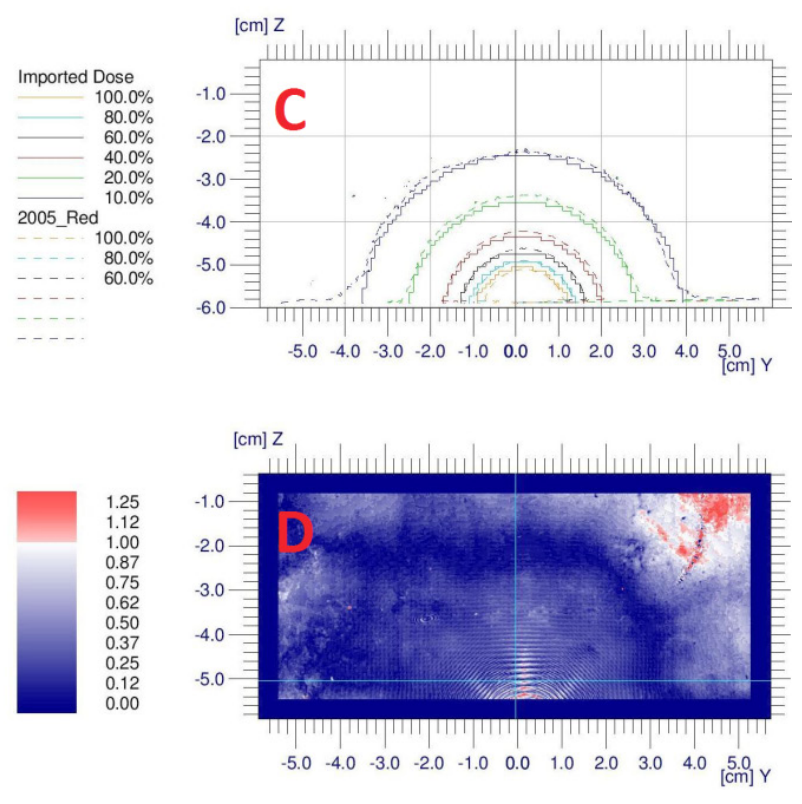

Rycina 1. Przykładowa analiza zaplanowanego i zmierzonego rozkładu dawki w płaszczyźnie prostopadłej do osi długiej źródła Ir-192. A - rozkład dawki z systemu planowania leczenia, B - rozkład dawki zmierzony filmem radiochromowym, $\mathrm{C}$ - izodozy z systemu planowania leczenia i odczytane z filmu, D - graficzne prezentacja analizy gamma [17].

\section{Kalibracja filmów dozymetrycznych}

Użycie do kalibracji wiązki promieniowania fotonowego wygenerowanego przez akcelerator znacznie ułatwia kalibrację filmów ze względu na łatwość pozycjonowania filmu w dowolnej odległości od źródła promieniowania, jak i możliwość uzyskania jednorodnego rozkładu dawki na całym napromienionym fragmencie. W ten sposób autorzy kilku publikacji przy użyciu wygenerowanych wiązek kilo- bądź megawoltowych tworzyli krzywe kalibracyjne, na podstawie których określali dawkę na filmach 
napromienionych źródłem o innej energii $[19,20]$. Ten sposób kalibracji filmów nie wydaje się jednak właściwy. Wynika to $\mathrm{z}$ faktu, że stanowisko badań, co do statystycznej nieistotności zależności reakcji filmów radiochromowych EBT na energię promieniowania jest różne i brak w tym temacie jednogłośności. W broszurze opublikowanej przez producenta filmów, Gafchromic EBT-self-developing film for radiotherapy dosimetry [21] opisano zależność odpowiedzi filmu dla tych samych dawek przy napromienianiu filmów rentgenowskimi wiązkami kilowoltowymi $(30 \mathrm{kVp}, 100 \mathrm{kVp}, 150 \mathrm{kVp})$ i kobaltem $\left({ }^{6 \circ} \mathrm{Co}\right)$ o średniej energii promieniowania wynoszącej 1,25 MeV. Dla takich warunków zmierzone wartości odpowiedzi filmu różniły się nie więcej niż o 5\%. W kolejnym przytoczonym w broszurze badaniu zależności energetycznej dla wysokoenergetycznych wiązek (6 MeV, $15 \mathrm{MeV}, 20 \mathrm{MeV})$ odpowiedź filmu była taka sama dla żądanych dawek. Porównując badania, zauważyć można znaczną różnicę w odpowiedzi filmów na energie poniżej 1,25 $\mathrm{MeV}$ i powyżej $6 \mathrm{MeV}$. Wynikać to może z różnej serii zastosowanych filmów, skanera, jak i sposobu obróbki danych, zatem oparto się o rezultaty badań przeprowadzonych w tych samych warunkach. Według pracy Brown i Hongstrom [22] dla dawek do 3 Gy zdeponowanych przy użyciu promieniowania o energii 25keV 4MV film EBT wykazuje znaczną czułość na energię promieniowania, podczas gdy Chiu-Tsao [23] dla energii $21 \mathrm{keV}-6 \mathrm{MV}$ w zakresie dawek do 3 Gy wykazał, że odpowiedź filmów EBT jest niemalże niezależna od energii promieniowania, pogarszając się w zakresie bardzo niskich energii. Do podobnych wniosków dla zakresu energii $50 \mathrm{kVp}-6 \mathrm{MV}$ doszedł Butson [24]. Wniosek o niewielkiej zależności energetycznej podtrzymuje w swojej pracy Rink, dokonując analizy filmów bezpośrednio po napromienieniu [25], gdzie dla zakresu energii $75 \mathrm{kVp}-18 \mathrm{MV}$ średnia różnica w odpowiedzi wyniosła 6\%. Największym przeciwwskazaniem dla kalibracji filmów we wiązce o innej energii jest praca Richtera [26], gdzie w badaniu dla wiązek $10 \mathrm{kVp}-$ $15 \mathrm{MV}$ w zakresie dawek od o do 10 Gy wykazano największą statystycznie istotną zależność energetyczną odpowiedzi filmów między energią $25 \mathrm{kVp}$ i $6 \mathrm{MV}$.

Różnica we wnioskach prac poruszających ten problem wynikać może z wielu czynników, spośród których duży wpływ ma narzędzie analizy filmu, którym w powyższych badaniach były densytometry, spektrometry i skanery z lampami o różnym spektrum.

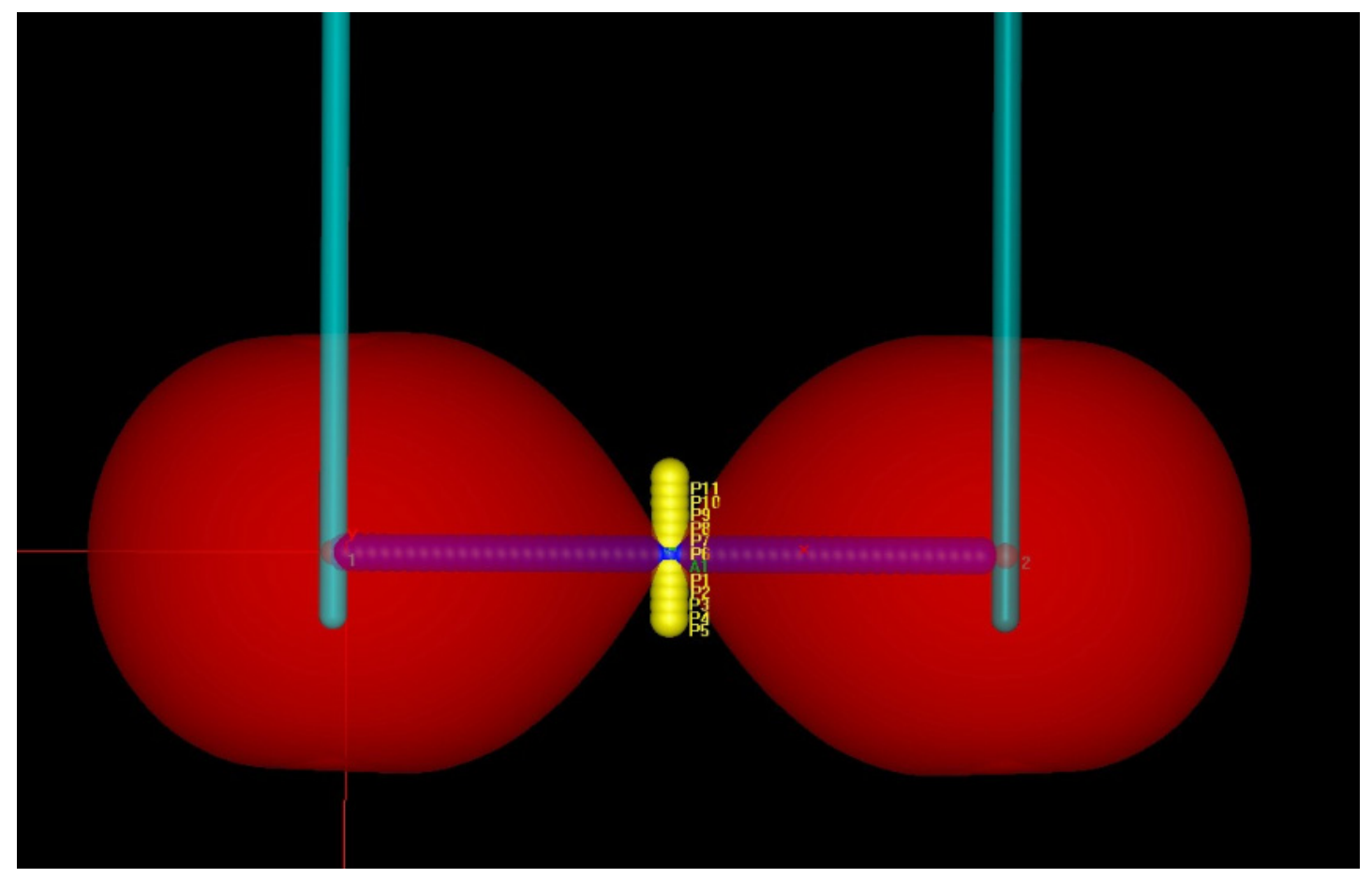

Rycina 2. Schemat rozkładu dawki w układzie do kalibracji filmu dozymetrycznego przy użyciu źródła Ir-192. Czerwona powierzchnia przedstawia izodozę 100\% dawki, żółte punkty miejsce umieszczenia filmu dozymetrycznego [17].

Podjęcie decyzji o kalibracjifilmów przy użyciuźródła ${ }^{192}$ Ir nie wymagałoby tak wnikliwejanalizy wszystkich możliwości, gdyby nie fakt, że napromienienie filmu jednorodną dawką z użyciem źródeł punktowych 
stosowanych w brachyterapii z jak najmniejszą niepewnością jest skrajnie trudne. Celem zmniejszenia niepewności wartości sygnału zarejestrowanego w obszarach zainteresowania odpowiadającego danej dawce, właściwy wydaje się być układ napromieniania stworzony przez Khushdeep Singh [27]. Jego istota polega na aktywowaniu po jednej pozycji postoju w dwóch naprzeciwlegle zamontowanych aplikatorach, film umieszczony pomiędzy aplikatorami (ryc. 2). Układ taki stworzyć można wykorzystując różne materiały tkankopodobne [28].

\section{Podsumowanie}

Wprowadzenie nowych algorytmów obliczeniowych w planowaniu brachyterapii wymusza zastosowanie znacznie bardziej dokładnych technik weryfikacji rozkładów dawek i wzięcia pod uwagę czynników pomijanych do tej pory. Zastosowanie radiochromowych filmów dozymetrycznych do weryfikacji rozkładów dawek w brachyterapii wydaje się być obiecującą techniką. Z powodu bardzo dużych gradientów dawki, punktowe pomiary dawki obarczone są bardzo dużą niepewnością pomiarową. Wprowadzenie analizy gamma z odpowiednim poziomem istotności i kryteriami: różnica dawki/odległość pozwala na porównanie zaplanowanego i zrealizowanego rozkładu dawki.

\section{Konflikt interesu / Conflict of interest}

Nie występuje / None

\section{Finansowanie / Financial suport}

Umowa grant WCO nr 30/2014(89) z dnia 9.12.2014 r. o realizację wyodrębnionego zadania badawczego w projekcie badawczym.

\section{Etyka / Ethics}

Treści przedstawione w artykule są zgodne z zasadami Deklaracji Helsińskiej, dyrektywami EU oraz ujednoliconymi wymaganiami dla czasopism biomedycznych.

\section{Piśmiennictwo / References}

[1] Malicki J. The importance of accurate treatment planning, delivery, and dose verification.Rep Pract Oncol Radiother. 2012; 17(2): 63-65

[2] Kirisits C, Rivard MJ, Baltas D et al. Review of clinical brachytherapy uncertainties: analysis guidelines of GEC-ESTRO and the AAPM. Radiother Oncol 2014; 110: 199-212

[3] Granero, D., Vijande, J., Ballester, F. et al, Dosimetry revisited for the HDR 192Ir brachytherapy source model mHDR-v2. Med Phys. 2011;38:487-494.

[4] Perez-Calatayud, J., Ballester, F., Das, R.K. et al, Dose calculation for photon-emitting brachytherapy sources with average energy higher than $50 \mathrm{keV}$ : Report of the AAPM and ESTRO. Med Phys. 2012;39:2904 - 2929.

[5] DeWerd L.A., Ibbott G.S., Meigooni A.S. A dosimetric uncertainty analysis for photon-emitting brachytherapy sources: report of AAPM Task Group No. 138 and GEC-ESTRO. Med Phys. 2011;38:782801.

[6] Adamczyk M, Zwierzchowski G, Malicki J, et al. Evaluation of clinical benefits achievable by using different optimization algorithms during real time prostate brachytherapy. Phys Medica. 2013;29(1):11117.

[7] Rivard MJ, Beaulieu L, Mourtada F. Enhancements to commissioning techniques and quality assurance of brachytherapy treatment planning systems that use model-based dose calculation algorithms. Med Phys. 2010;37(6):2645-58.

[8] Palmer A, Bradley D, Nisbet A. Physics-aspects of dose accuracy in high dose rate (HDR) brachytherapy: 
source dosimetry, treatment planning, equipment performance and in vivo verification techniques. J Contemp Brachytherapy. 2012 Jun;4(2):81-91

[9] Damato AL, Cormack RA, Viswanathan AN. A novel intracavitary applicator design for the treatment of deep vaginal fornices: preliminary dose metrics and geometric analysis. J Contemp Brachytherapy. 2015 Feb;7(1):48-54

[10] Hyer D.E., Sheybani A., Jacobson G.M., et al. The dosimetric impact of heterogeneity corrections in high-dose rate (192)Ir brachytherapy for cervical cancer: investigation of both conventional Point-A and volume-optimized plans. Brachytherapy. 2012;11:515-520.

[11] Beaulieu L, Carlsson Tedgren A, Carrier JF, et al. Report of the Task Group 186 on model-based dose calculation methods in brachytherapy beyond the TG-43 formalism: current status and recommendations for clinical implementation. Med Phys. 2012;39(10):6208-36.

[12] Oliveira SM, Teixeira NJ, Fernandes L, et al. Dosimetric effect of tissue heterogeneity for 125I prostate implants. Rep Pract Oncol Radiother, 2014; 19(6) : 392-398

[13] Vivekanandan N, A Quality Assurance Test Based On Gamma Analysis of Fluence Test Patterns for HDR Brachytherapy, Med. Phys. 35, 2781 (2008)

[14] Devic S, Tomic N, DeBlois F, Brachytherapy TPS QA Using EBT Model GafChromic Film, Med. Phys. 36, 2528 (2009)

[15] Nelms B.E, Simon J.A, A Survey of planar IMRT QA analysis, J Appl Clin Med Phys, vol. 8, pp. 1-15, 2007

[16] Krause F., Krause T, Siebert F. A., Commissioning of a model-based dose calculation algorithm for brachytherapy according to the TG-186 report. 3rd ESTRO Forum Barcelona 2015

[17] Bielęda G., Zwierzchowski G., Mikolajczak J., Can gamma analysis using radiochromich films be a reliable method to verify MBDCA reported by AAPM TG-186. 3rd ESTRO Forum Barcelona 2015

[18] Kowalik A. Ocena ryzyka, kontrola jakości i bezpieczeństwa w radioterapii w świetle doniesień konferencyjnych 3rd ESTRO Forum w Barcelonie, Zeszyty Naukowe WCO, Letters in Oncology Science 2016;13(4):73-78

[19] Tabrizi S.H et al, Dosimetric evaluation of a novel high dose rate (HDR) intraluminal/interstitial brachytherapy applicator for gastrointestinal and bladder cancers, Journal Of Applied Clinical Medical Physics, Volume 12, Number 1, Winter 2011

[20] Uniyal S.C, Radiochromic film dosimetry of rectal inhomogeneity and applicator attenuation in high dose rate brachytherapy of uterine cervix, J Appl Clin Med Phys. 2012 Jan 5;13(1):3654

[21] Gafchromic EBT - self - developing film for radiotherapy dosimetry, ISP, 2007 (online1.ispcorp.com/ Gafchromic/content/products/ebt/pdfs/EBTwhitepaper.pdf)

[22] Brown. T, Hogstrom R.K, Dose-response curve of EBT, EBT2 and EBT3 radiochromic films to synchrotron-produced monochromatic x-ray beams, Med Phys. 2012 Dec;39(12):7412-7

[23] Chiu-Tsao et al., Energy dependence of response of new high sensitiviy radiochromic films for megavoltage and kilovoltage radiation energies, Med Phys. 2005 Nov;32(11):3350-4.

[24] Butson et al., Weak energy dependence of EBT gafchromic film dose response in the $50 \mathrm{kVp}-10 \mathrm{MVp}$ X-ray range, Appl Radiat Isot. 2006 Jan;64(1):60-2. Epub 2005 Aug 18.

[25] Rink A. et al., Energy dependence ( $75 \mathrm{kVp}$ to $18 \mathrm{MV}$ ) of radiochromic films assessed using a real-time optical dosimeter, Med Phys. 2007 Feb;34(2):458-63

[26] Richter C. et al., Energy dependence of EBT-1 radiochromic film response for photon (10 kVp - 15 MVp) and electron beams $(6-18 \mathrm{MeV})$ readout by a flatbed scanner, Med Phys. 2009 Dec;36(12):5506-14

[27] Khushdeep Singh, Investigation of the energy response of EBT-2 gafchromic film model, Department of Medical Physics, McGill University, Montreal, December 2011

[28] Zwierzchowski G., et al., Film based verification of calculation algorithms used for brachytherapy planning-getting ready for upcoming challenges of MBDCA J Contemp Brachytherapy. 2016 Aug; 8(4): $326-335$. 